\title{
A Holistic Approach for Addressing the Issue of Effective Technology Transfer in the Frame of Climate Change
}

\author{
Charikleia Karakosta \\ School of Electrical and Computer Engineering, Decision Support Systems Laboratory, Energy Policy Unit, \\ National Technical University of Athens, 9, Iroon Polytechniou Str., Athens 15780, Greece; chkara@epu.ntua.gr; \\ Tel.: +30-210-772-2084
}

Academic Editor: Vincenzo Dovì

Received: 4 March 2016; Accepted: 20 April 2016; Published: 30 June 2016

\begin{abstract}
Climate change policy and sustainable development issues and goals are closely intertwined. Recognizing the dual relationship between sustainable development and climate change points to a need for the exploration of actions that jointly address sustainable development and climate change. Technology transfer is considered an issue with growing interest worldwide and has been recognized as the key in supporting countries to achieve sustainable development, while addressing climate change challenges. This study presents an integrated decision support methodological framework for the formulation and evaluation of activities to promote technology transfer, as well as the provision of clear recommendations and strategies for framing specific policy in the context of climate change. The philosophy of the proposed approach, under the name: assess-identify-define (AID), consists of three components, where each one focuses on a particular problem. The methodology is integrated using appropriate tools in the information decision support system for effective technology transfer (DSS-ETT). The pilot application of the proposed methodology, in five representative developing countries, provided the possibility to evaluate the characteristics of the adopted methodology in terms of completeness, usability, extensionality, as well as analysis of results reliability.
\end{abstract}

Keywords: technology transfer; climate change; sustainable development; developing world; energy sector; decision support; multicriteria analysis; econometria

\section{Introduction}

Technology transfer is considered an issue with growing interest worldwide and has been recognized as a key factor for developing countries to achieve sustainable development, especially in a view of the climate change challenge [1-3]. The complexity of the technology transfer process requires effective cooperation among stakeholders [4], as well as an assessment of the factors affecting it. One of the major factors, if not the most important, influencing the technology transfer process and the effectiveness of the transferred know-how, is the conditions in the recipient country and the innovative perspective [5].

The road of the international climate negotiations towards the 21st United Nations Framework Convention on Climate Change (UNFCCC) Conference of Parties (COP21) has been marked by a "shift from global efforts to domestic processes, as well as a move from commitments to contributions" [6]. The diversity among developing countries makes it more than clear that the approach for an effective technology transfer towards sustainable development should take into account the host country characteristics $[7,8]$.

One of the key preconditions for fostering technology transfer is the active participation and the empowered role of all decision makers groups in this process [9]. Moreover, a crucial criterion for 
the successful technology transfer in a country is the development of the recipient's ability to utilize the transferred know-how for the benefit of all involved stakeholders. Based on the above, it is an undeniable fact that the problem of achieving effective technology transfer is a realistic balance among the use of scientific techniques, knowledge and stakeholders experience [10].

The efforts so far to transfer technologies for climate change mitigation effectively to developing are limited and sporadic, without necessarily being in line the host country's energy needs and priorities [11,12]. In addition, most of these efforts fail to actively and efficiently involve all related stakeholders, key experts, market players and decision makers during all stages of technology transfer process, so as to reduce potential barriers and avoid the risk of inefficient decisions and actions [13-15].

Moreover, the impact of climate change differentiate over time the energy needs and objectives of sustainable development of a country, which clearly affects its technological needs. It is interesting to explore, e.g., whether natural resources needed for a technology might be affected by a changing climate and thus make the technology less appropriate for the country or whether climate change might require different energy services (e.g., cooling) in the country. A focus exclusively on present climatic circumstances would fail to incorporate such aspects.

In the above framework, a flexible methodological framework, using original tools, analysing related factors and induced interactions, dealing with the problem of forming concrete strategies for the promotion of effective technology transfer in a coherent and comprehensive manner, is considered essential. This paper proposes a methodological approach that tries to meet the need for a clear definition and understanding of the relationship among sustainable development goals, energy needs and technological capabilities, while taking into account the developing country's specific characteristics, as well as the particularities of stakeholders involved in the related energy market.

Based on the investigation of the characteristics of the problem and the parameters to be taken into account, this paper discusses the philosophy and process of the proposed approach—assess-identify-define (AID)—its individual components and multi-criteria methodologies used. Finally, the supporting information system developed based on the proposed methodology is briefly presented, aiming at providing a useful decision support tool for the promotion of technology transfer to the developing world. A pilot application to five representative developing countries is implemented. The paper closes with the presentation of the conclusions arising from the above analysis.

\section{The Philosophy}

This section emphasizes on the detail presentation of the philosophy of the proposed methodological approach, which forms the basis for the promotion of effective technology transfer to the developing world in the light of climate change.

The philosophy of the proposed approach aims to fulfil the need for a clear definition and understanding of the relationship between energy objectives and technological needs of a developing country for an effective technology transfer, as these are redefined by the impact of climate change, while achieving sustainable development. Such an approach can serve as "guidance" for the host developing country, so as to avoid decisions made about the transfer of sustainable energy technologies without considering the country's energy policy and strategy towards sustainable development. The philosophy of the proposed approach, with the name AID, consists three successive components (Figure 1), where each one focuses on a particular problem:

\subsection{1st Component-Assess}

The first component, Assess, concerns the definition of the problem characteristics, as well as the assessment of the host developing country energy needs and priorities in accordance with its long-term objectives for sustainable development and in the light of climate change. 


\subsection{2nd Component-Identify}

The second component, Identify, deals with the evaluation and identification of the most suitable for the host country sustainable energy technologies to be transferred. The identified technologies address the energy needs of the developing country, while they respond to the country's strategic objectives for social, environmental and economic sustainability.

\subsection{3rd Component-Define}

Finally, the third component, Define, refers to the definition of strategic actions, programs and specific guidelines for the creation of an appropriate enabling environment and the formulation of comprehensive proposals to promote the effective technology transfer in the developing country.

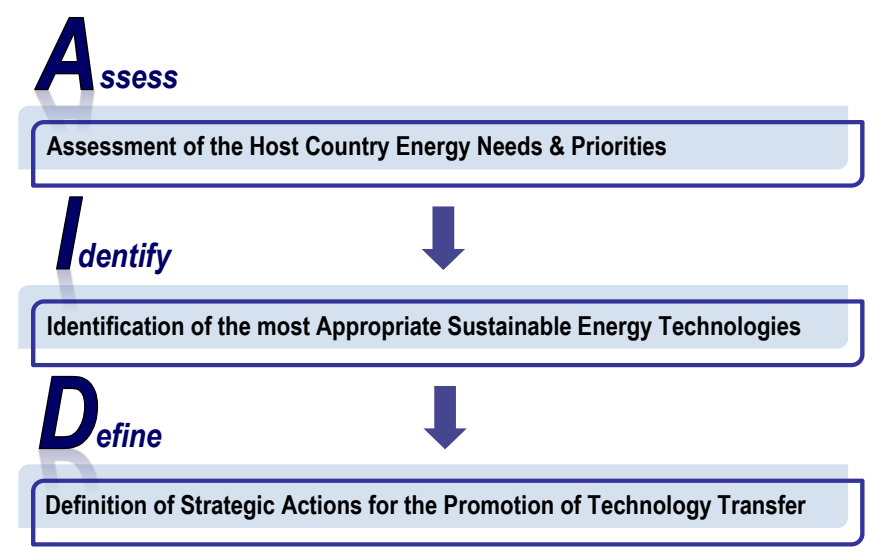

Figure 1. The assess-identify-define (AID) approach.

\section{The Methodological Approach}

The flow chart that summarizes the proposed methodological approach, which underpins the philosophy, is shown in Figure 2.

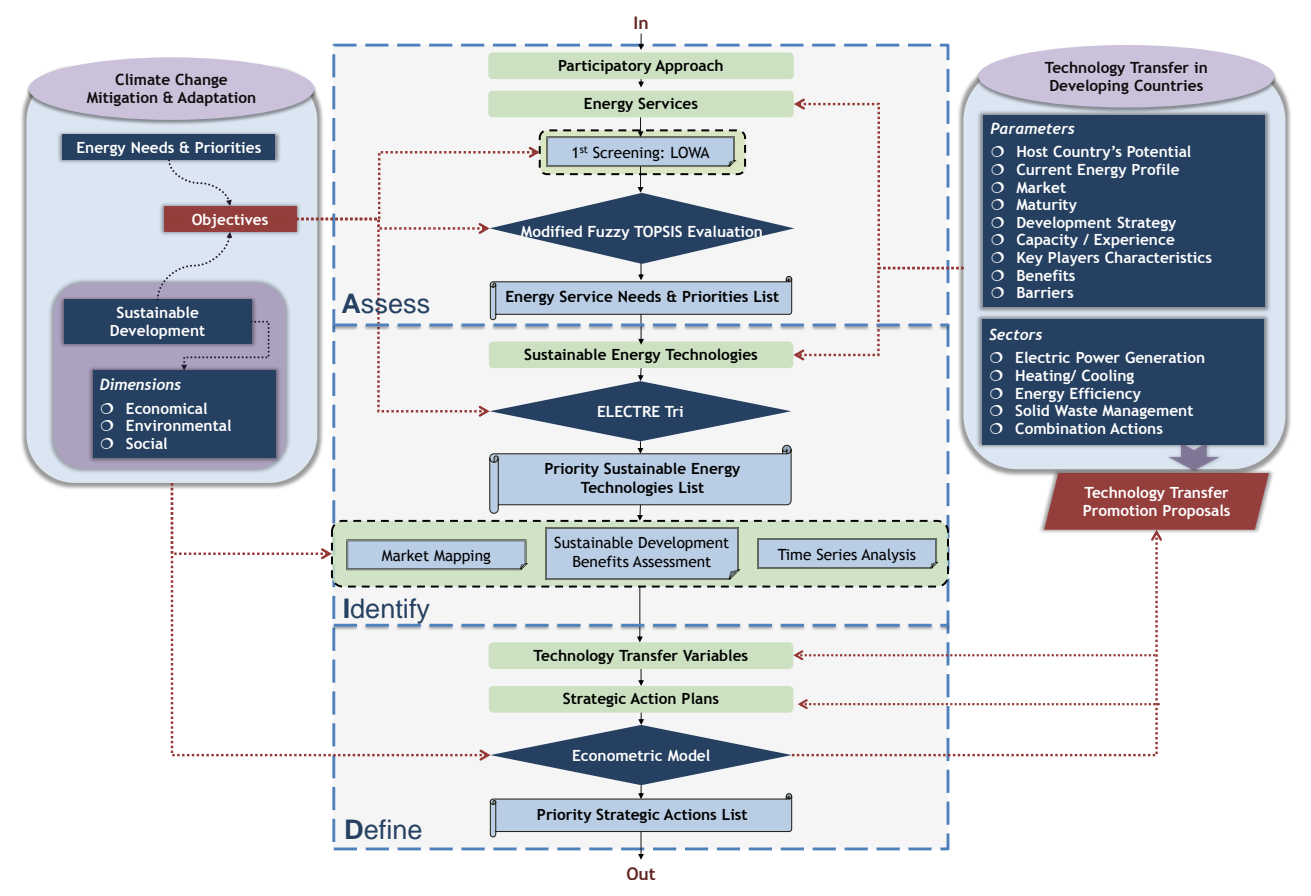

Figure 2. The process of the proposed methodological approach AID. 
In particular, step by step the approach proposed can be described as in the following paragraphs. The conditions in the host country and its perspectives are affecting the technology transfer, the know-how process and its effectiveness. In this context, at this stage various related parameters are categorized, so that they can be imported into the next stages of the methodology. In particular:

- Initially the indicators that reflect the current state of the host country, so as to consolidate and better understand its specific characteristics are identified.

- A broad range of sub-sectors or energy services are identified for the study. The study focuses on mitigation types of action only.

- Selection of technologies that are rather broad by identifying from a range of literature sources, clean, sustainable energy technologies that might be applicable for the host country.

- The factors that affect and contribute to the technology transfer are identified.

- Identification of supporting actions for technology transfer for each country context and implemented as an integral part of the transfer process.

\subsection{Participatory Approach}

The particular methodological process requires a participatory approach for engaging the relevant energy and environment decision and policy-making stakeholders in the host countries. A simple, coherent and organized process is followed for the necessary data collection and input elicitation based on experts' preferences. This approach is constructed based on participatory methods and collaborative techniques [16]. Among others, it allows a mapping of key stakeholders, stakeholders' selection according to specific criteria, bilateral contacts with stakeholders and structured interviews facilitated by an appropriate developed for this purpose questionnaire. Participatory consultations enable the active stakeholders' participation, communication and engagement in the process; facilitate the enrichment and collection of missing data, as well as the validation and verification of information provided [17,18].

\subsection{Energy Services}

At this stage a broad range of sub-sectors or energy services are identified for the study.

\subsection{Modified Fuzzy Technique for Order Preference by Similarity to Ideal Solution}

After defining the alternative energy services, the methodology proceeds with the assessment of the host country's energy services needs and priorities, so as to identify those energy services address better the country's energy policy and sustainable development objectives. For the above purpose a multi-criteria approach, and particular an extension of Fuzzy Technique for Order Preference by Similarity to Ideal Solution (TOPSIS) for group decision-making, where different decision makers participate, is developed $[19,20]$. The criteria for the ranking these energy services needs and priorities are based on the need for increased access to energy, need for reliable energy supply and larger need for affordable energy supply.

\subsection{1st Screening: Linguistic Ordered Weighted Averaging}

An initial qualitative assessment of all alternative energy services can be implemented, using the linguistic ordered weighted average (LOWA) method [21]. This stage is considered as a verification and validation check of the final results.

\subsection{Energy Service Needs and Priorities List}

After the Modified Fuzzy TOPSIS assessment, the list of priority energy services contributing the most to the country's need for increased access to energy, need for reliable energy supply and larger need for affordable energy supply is formulated. 


\subsection{Sustainable Energy Technologies}

The alternative sustainable energy technologies that could deliver the country's energy services are introduced at this stage. The definition of the sustainable energy technologies is essential in trying to link these technologies with the host country's energy needs and priorities.

\subsection{ELECTRE TRI}

The approach proceeds with the formulation of a decision support framework for the identification of the most suitable sustainable energy technologies to be transferred to the host country, so that along with the benefits of reducing greenhouse gas emissions, to address also the country's energy needs and priorities, according to its objectives for social, environmental and economic sustainability. The adopted approach uses an existing multi criteria decision making (MCDM) method customized within the specific problem characteristics, namely the ELECTRE TRI Method [22,23]. The method integrates specific functionalities facilitating the decision maker by incorporating direct stakeholders' preferences at the elicitation process.

\subsection{Priority Sustainable Energy Technologies List}

The methodology continues with the classification of sustainable energy technology options in specific prioritized for addressing the host country's specific energy needs.

\subsection{Market Mapping}

After identifying the most appropriate sustainable energy technologies to be transferred to a certain host country, a market mapping exercise could be conducted, so as to explore the implementation chain circumstances of these sustainable energy technologies. This exercise is conducted as further check and analysis of the resulted as priority sustainable energy technologies for the host country, so as to crosscheck the results at this stage. The approach for exploring technology implementation chains is that of Market Mapping, which was originally proposed by Albu and Griffiths [24] and which describes the system for technology diffusion by dividing it into three elements: the business enabling environment; the market chain; and the market supporting services.

\subsection{Sustainable Development Benefits Assessment}

In another parallel stage, the resulted as priority sustainable energy technologies are assessed regarding the sustainability development benefits they could deliver to a developing country. Thus, appropriate sustainable development criteria and indicators are selected to measure the priority energy technologies performance according to sustainable development benefits-dimensions, namely environmental, social and economic. A qualitative text analysis is adopted. The project design documents (PDDs) of clean development mechanism (CDM) projects were the main data source for the analysis. The particular documents include genuine information about the CDM projects, as they are validated by the UNFCCC accredited the third party (the designated operating entity) agencies and approved by the CDM Executive Board (EB) [25]. The software program Nvivo7 [26,27], developed for qualitative text analysis, facilitates the organization, storage, retrieval and analysis of the qualitative data that derive from the PDDs.

\subsection{Time Series Analysis}

In this parallel stage, a statistical analysis is conducted to forecast which types of technology are more likely to involve technology transfer. In particular, the analysis time-series forecasting as the forecasting method, and particularly the crystal ball (CB) predictor to examine the data and predict what the future trends will be [28]. 


\subsection{Technology Transfer Variables}

At this stage, the technology transfer variables, influencing positively or negatively the technology transfer process in a developing count, are defined.

\subsection{Strategic Action Plans}

The strategic actions to promote the effective transfer of a sustainable energy technology in a developing country, in association with the identified factors/variables influencing the process of technology transfer are specified in this step.

\subsection{Econometric Model}

In this phase, an econometric model is built in order to analyze the impact of the explanatory variables on the overall rate of technology transfer in the host country, through the analysis of the host country's situation and infrastructure. Econometric analysis can serve as a useful tool for this purpose, as it facilitates the study of the causal effect of one variable on another. An econometric model will be used to indicate the effect of one variable on the likelihood that a project involves technology transfer on another, keeping all other variables constant that could render an effect on the second variable. Understanding the logical framework of technology transfer in the light of climate change, is what will lead to the proposal of a long-term strategy for technology development and transfer, as well as of specific strategic actions to promote the transfer of sustainable energy technologies to the host country.

\subsection{Priority Strategic Actions List}

The results of the econometric model are combined with a rule based system, so as to result to concrete to strategic actions for achieving real and effective technology transfer in a developing country. Thus, in this stage the conditions, strategies and policies in place that could create the right dynamic environment, as well as a "package" of capacity building activities to promote effective technology transfer to a developing country are outlined.

\section{Key Features of the Approach}

\subsection{1st Component-Assess: Assessment of the Host Country Needs and Priorities}

This section presents the procedure to be followed under the proposed methodology for assessing the developing country's energy needs and priorities, in order to identify those that are in line with its energy policy and sustainable development goals. The methodological approach followed is graphically shown in Figure 3 and key features are discussed in the following paragraphs.

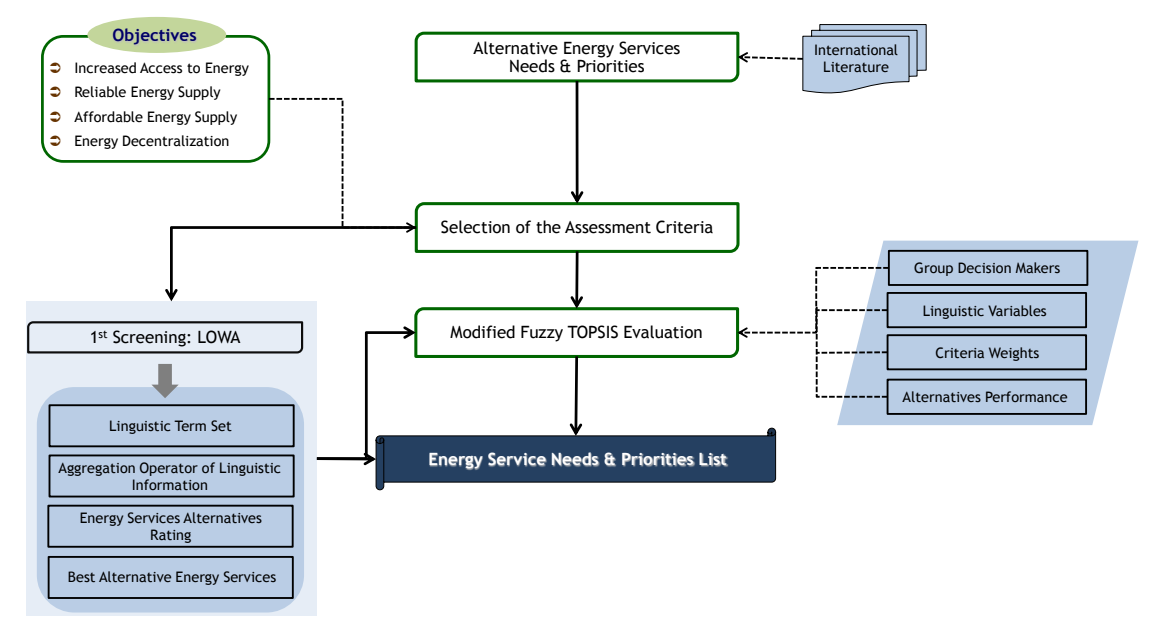

Figure 3. 1st component-assess. 
Information and data for the particular component are imprecise and uncertain, since the nature of the assessment of the host country needs and priorities is qualitative and therefore it is very difficult to be depicted in numerical values. Thus, a realistic approach is the use of linguistic variables in the processes of the different multi-criteria methods, which are composed of a finite set of linguistic terms and their meaning is a fuzzy subset in a universe of discourse. Indeed, linguistic approaches have been widely used in different fields, such as technology transfer strategy selection, assessment of energy technology options, energy and environmental policy, corporate policy, etc. [11,29-32].

The LOWA operator (based on the ordered weighted average (OWA) operator and the convex combination of linguistic labels) built on the symbolic approach, aggregates linguistic information provided for different criteria which are equally important [21], were used for an initial qualitative assessment of all alternative energy services. In order to result to the final list of energy need and priorities for the host country an extension of fuzzy TOPSIS for group decision making is used. The multicriteria method TOPSIS considers that the chosen alternative should have the shortest distance from the positive ideal solution and the longest distance from the negative ideal solution. Fuzzy TOPSIS incorporates fuzzy numbers in the process, measuring the distance between two triangular fuzzy numbers by a vertex method resulting in a crisp distance value and use the ideal and non-ideal solutions to define a crisp overall score for each alternative [19].

It is noted that for the purpose of this proposed approach the focus is on mitigation types of action and particularly decentralised energy systems and increased efficiency of fuel conversion activities. Within these three areas, a broad range of energy services have been, namely [11]:

- N1: Electricity for industry

- N2: Electricity for agriculture

- N3: Electricity for households: rural communities

- N4: Electricity for households: urban communities

- N5: Electricity for service sectors

- N6: Heat for industry

- N7: Heat for households

- N8: Heat for service sectors

The criteria to be used for the assessment of the priority energy services in the specific developing countries are the following [11,33-35]:

- $\quad$ C1: Need for increased access to energy

- $\quad$ C2: Need for reliable energy supply

- C3: Need for affordable energy supply

- C4: Need for energy decentralization

\subsection{2nd Component-Identify: Identification of the most Appropriate Sustainable Energy Technologies}

This section presents the procedure followed, for assessing and identifying the most appropriate sustainable energy technologies to be transferred to a host country that also address its energy needs, while are in line with the country's objectives for social, environmental and economic sustainable development.

The assessment was based on one of the most popular outranking techniques, the ELECTRE TRI method, after some appropriate adjustments. The ELECTRE TRI method from the Electre family was selected, which has been applied in problems related to environmental planning, risk analysis, CDM projects assessment etc. [7,12,36,37]. ELECTRE TRI concept is based on assigning alternatives to pre-defined categories and thus simulating decision-makers behaviour, which is usually characterised by a progressive transition from the indifference to the preference state [38]. The methodological approach followed graphically shown in Figure 4. 


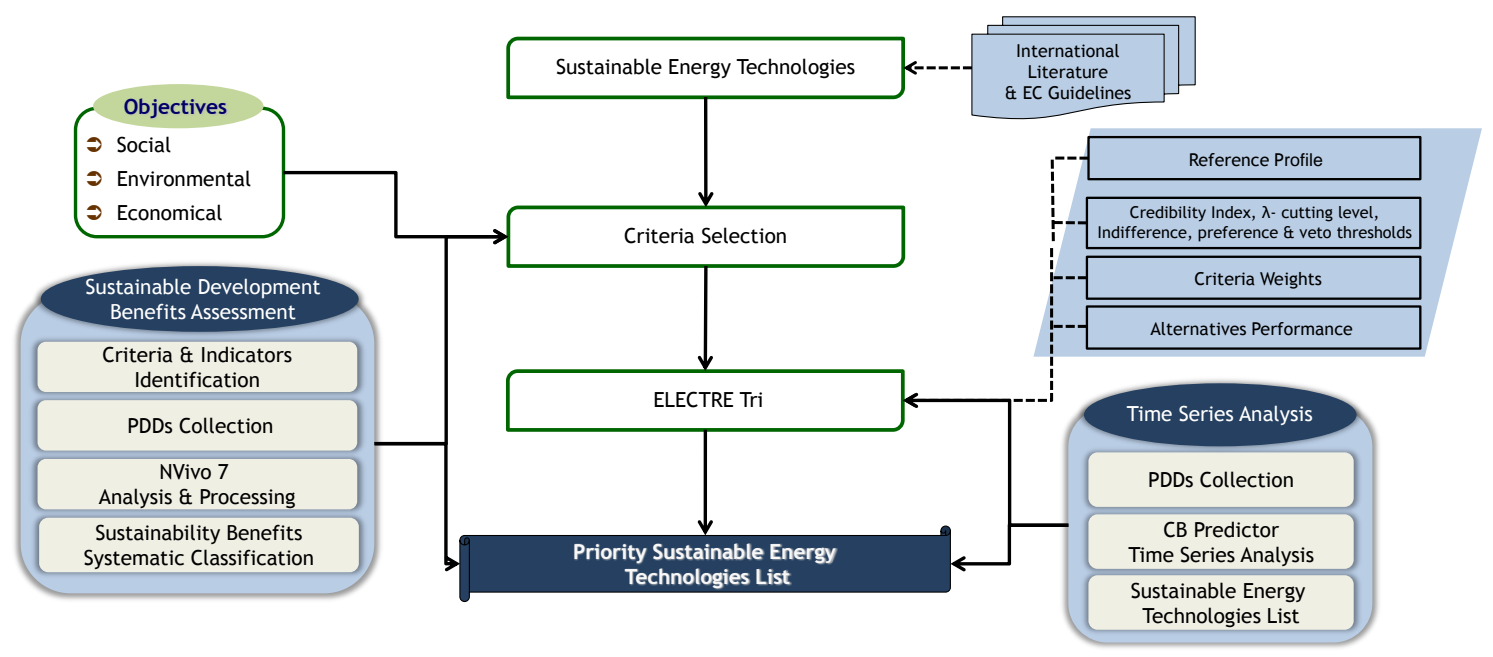

Figure 4. 2nd component-identify.

In advance, a desk study analysis was elaborated for the identification of the sustainable energy technologies for fulfilling the energy services needs and priorities assessed in the 1st component. The selection of technologies has been rather broad by identifying from a range of literature sources [39-44] clean, sustainable energy technologies that might be applicable. The alternative sustainable energy technologies categories identified were 43 and comprise energy service categories, such as electricity generation, heating, cooling, energy efficiency, and municipal solid waste (MSW). The sustainable energy technologies finally selected are listed in Table 1.

Table 1. The alternative sustainable energy technologies [7,45-52]. SC: supercritical; PC: pulverised coal; CMM: coal mine methane; CHP: combined heat and power; IGCC: integrated gasification combined cycle; CSP: concentrating solar power; CFL: compact fluorescent lamps; and MSW: municipal solid waste.

\begin{tabular}{|c|c|c|}
\hline Energy Needs & Energy services alternatives & Sustainable Energy Technology Alternatives \\
\hline Electricity & $\begin{array}{l}\text { N1: Electricity for industry; } \\
\text { N2: Electricity for agriculture; } \\
\text { N3: Electricity for } \\
\text { households-rural communities; } \\
\text { N4: Electricity for } \\
\text { households-urban communities; } \\
\text { N5: Electricity for service sectors }\end{array}$ & $\begin{array}{l}\text { T1: Biomass gasification; T2: Steam boiler upgrading; T3: Wind } \\
\text { energy; T4: SC PC; power plants; T5: Oil steam improvement; } \\
\text { T6: Coal steam improvement; T7: Biogas; T8: Geothermal energy; } \\
\text { T9: Solar lanterns; T10: Solar energy (PV); T11: Solar towers; } \\
\text { T12: Solar pods; T13: Ocean, wave and tidal energy; T14: Hydro } \\
\text { (dams); T15: CMM; T16: Coal-to-gas; T17: Small-scale hydro } \\
\text { energy; T18: Small-scale CHP production; T19: Mini/micro hydro } \\
\text { (rivers); T20: IGCC power plants; T21: CHP coal/gas-based; } \\
\text { T22: CSP; T23: Biomass combustion for electricity and heat; } \\
\text { T24: Methane capture at landfills for electricity; T25: Clean coal; } \\
\text { T26: Hybrid technology; T27: Hydrogen }\end{array}$ \\
\hline Heat & $\begin{array}{l}\text { N6: Heat for industry; } \\
\text { N7: Heat for households; } \\
\text { N8: Heat for service sectors }\end{array}$ & $\begin{array}{l}\text { T28: Heat pumps for space heating/cooling and water heating; } \\
\text { T29: Solar thermal; T30: Solar pods; T31: Small-scale CHP } \\
\text { production; T32: CHP coal/gas-Based; T33: Biomass combustion } \\
\text { for electricity and heat }\end{array}$ \\
\hline Cooling & $\begin{array}{l}\text { N9: Energy for Cooling for } \\
\text { all Sectors }\end{array}$ & $\begin{array}{l}\text { T34: Heat pumps for space heating/cooling and water heating; } \\
\text { T35: Solar cooling and hybrid systems with heating and hot water }\end{array}$ \\
\hline $\begin{array}{l}\text { Energy } \\
\text { Efficiency }\end{array}$ & N10: Energy Efficiency in Industry & $\begin{array}{l}\text { T36: Energy efficiency in buildings; T37: Energy efficiency in iron } \\
\text { and steel industry; T38: Energy efficiency in the cement industry; } \\
\text { T39: Energy efficiency in the agrifood industry; T40: CFL }\end{array}$ \\
\hline $\begin{array}{c}\text { Waste } \\
\text { Management }\end{array}$ & $\begin{array}{l}\text { N11: MSW management } \\
\text { for energy }\end{array}$ & $\begin{array}{l}\text { T41: Gasification of MSW for large-scale electricity /heat; } \\
\text { T42: Landfill gas methane capture (MSW); T43: Combustion } \\
\text { of MSW }\end{array}$ \\
\hline
\end{tabular}


For the assessment of these technologies a number of sustainable objectives had to be incorporated in the analysis, such as social impacts, greenhouse gases reductions and environmental impacts, in accordance to the particularities, development needs and perspectives of the examined host country. The research focuses on the provision of a small but clearly understood set of evaluation criteria, which can form a sound basis for the assessment of the sustainable energy technology alternatives in terms of their contribution to sustainable development goals. In brief, the six criteria that integrate the benefits in the economic, environmental and social aspect are [7,12,53-55]:

- $\quad \mathrm{K} 1$-Accordance with strategic/developmental planning: Reflects the accordance of particular technologies with the strategic and developmental planning of each country. The higher the accordance with strategic planning in a specific country the higher the performance of a specific technology in this criterion;

- K2-Local and regional economic development: Represents the repercussion of a particular technology in the local and regional development. It does not include the impact on the employment, while it incorporates the extent to which the local enterprises bloom due to the investments in the region. The higher the growth achieved the higher the performance;

- $\mathrm{K} 3-\mathrm{CO}_{2}$ emissions reduction: Represents the estimated reduction of $\mathrm{CO}_{2}$ emissions that will be achieved via the implementation of each alternative. The choices with the higher possible reduction are evaluated higher than the options with lower $\mathrm{CO}_{2}$ reduction potential;

- K4-Minimization of the negative effects on the Natural environment at national—regional level: Reflects the level of repercussion of the alternative in the natural environment, incorporating the noise levels, aesthetic interruptions, pressure on land resources and excessive land use. Options with the least possible impact are ranked higher;

- K5-Contribution to the employment: The criterion is about the social impact that the alternative has, as far as the employment rates are concerned. The higher the contribution to net employment generation, the higher the performance in this criterion;

- $\quad$ K6-Contribution to the energy sufficiency (independence): This criterion depicts the extent to which each examined option contributes to the country's energy independence, by substituting certain amounts of the consumed primary energy.

\subsection{3rd Component-Define: Definition of Strategic Actions for the Promotion of Technology Transfer}

Figure 5 illustrates the procedure followed to define the actions, guidelines and strategies to promote the effective technology transfer to a host country in light of climate change.

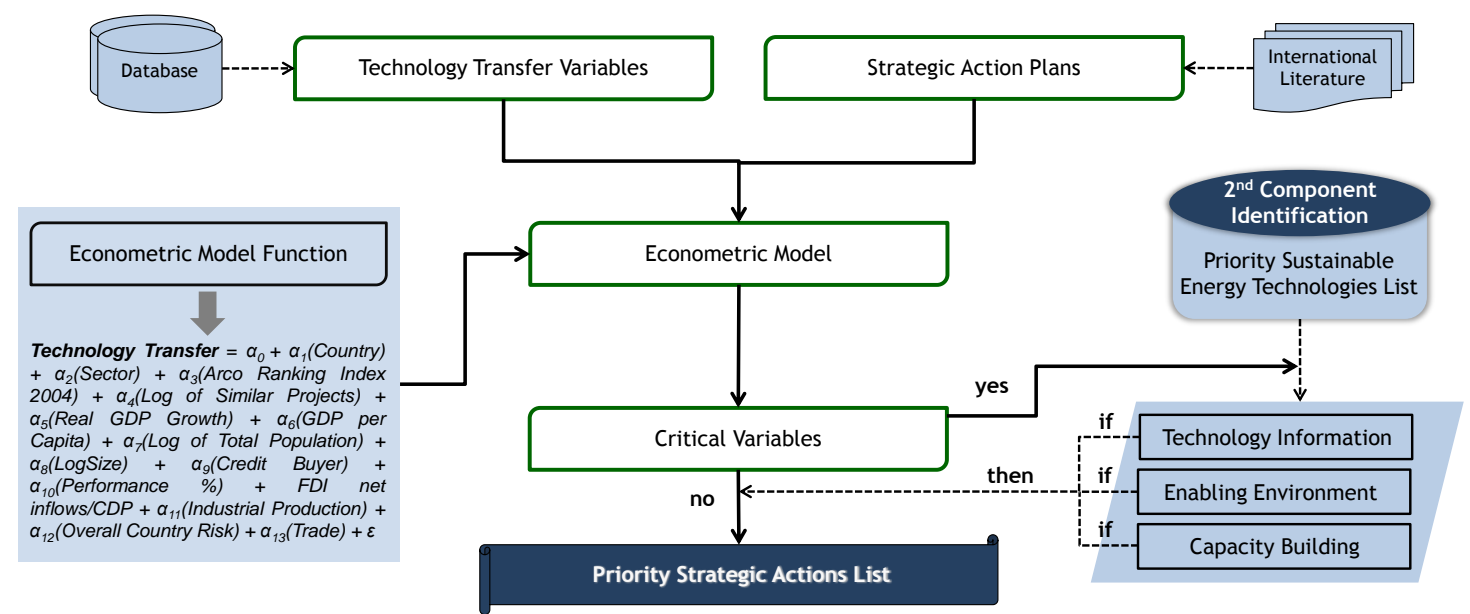

Figure 5. 3rd component-define. 
Based on literature review the variables promoting or hampering the transfer of technology across countries used for this approach are Country; Sector; Arco ranking index 2004; Log of similar projects; real gross domestic product (GDP) growth (annual) 2006-2010 (\%); GDP/capita, 2009 (In nominal U.S. dollars); Log of total population (in million) 2009; LogSize $\left(\mathrm{ktCO}_{2} / \mathrm{yr}\right)$; Credit buyers; Performance against 6 World Bank governance indicators (\%); FDI net inflows/GDP 2009; Industrial Production Growth (annual) 2006-2010 (\%); Overall Country Risk; Trade 2006-10 (Merchandise Imports + Exports)/GDP [56-58].

The following paragraphs summarize the identified strategic actions to be a taken by a country, so as to accelerate the development and transfer of the priority technologies. The actions are groups in three general categories, namely technology information, enabling environment, and capacity building [59-66]. More particular:

$S_{\mathrm{a}}$ : Technology information

- $S_{\mathrm{a} 1}$ : Implementation of training programmes and workshops for building capacity in technology information

- $S_{\mathrm{a} 2}$ : Elaboration of national communications with information on technology transfer activities

- $S_{\mathrm{a} 3}$ : Elaboration of technical studies that explore barriers, good practices and recommendations

- $S_{\mathrm{a} 4}$ : Elaboration of reports on the Research and Development (R\&D) needs

- $S_{\mathrm{a} 5}$ : Establishment of technology information centres and networks

$S_{\mathrm{b}}$ : Enabling environment

- $S_{\mathrm{b} 1}$ : Creation of an environment conducive to investment

- $S_{\mathrm{b} 2}$ : Strengthening the regulatory frameworks/enhancement of legal systems

- $S_{\mathrm{b} 3}$ : Integration of technology transfer into national policies

- $\quad S_{\mathrm{b} 4}$ : Bilateral and multilateral cooperation programmes for the promotion of technology transfer

- $S_{\mathrm{b} 5}$ : Policy arrangements for the promotion of international scientific and technological cooperation

$S_{\mathrm{c}}$ : Capacity building

- $\quad S_{\mathrm{c} 1}: \mathrm{R} \& \mathrm{D}$ funding programs

- $S_{\mathrm{c} 2}$ : Elaboration of reports on capacity-building needs and experiences of the host country relating to the development, deployment, diffusion and transfer of technologies

- $S_{\mathrm{c} 3}$ : Activities to increase, enhance or improve awareness and knowledge of sustainable energy technologies and their transfer in a host country

- $S_{\mathrm{c} 4}$ : Establishment of national or regional R\&D centers

- $S_{\mathrm{c} 5}$ : Provision or support training activities for the development and transfer of technologies in a host country

The econometric model which is proposed to be used is presented below. Let Technology Transfer indicate a binary variable that is equal to 1 when a project involves technology transfer (without considering the nature of this technology transfer), while it is equal to 0 otherwise.

$$
\begin{aligned}
\text { Technology transfer }= & \alpha_{0}+\alpha_{1}(\text { Country })+\alpha_{2}(\text { Sector })+\alpha_{3}(\text { Arco Ranking Index 2004) }+ \\
& \alpha_{4}(\text { Log of Similar Projects })+\alpha_{5}(\text { Real GDP Growth })+\alpha_{6}(\text { GDP } / \text { capita })+ \\
& \alpha_{7}(\text { Log of Total Population })+\alpha_{8}(\text { LogSize })+\alpha_{9}(\text { Credit Buyer })+ \\
& \alpha_{10}(\text { Performance } \%)+\text { FDI net inflows } / \text { CDP }+\alpha_{11}(\text { Industrial Production })+ \\
& \alpha_{12}(\text { Overall Country Risk })+\alpha_{13}+\varepsilon
\end{aligned}
$$

where, $\alpha_{0}, \alpha_{1}, \alpha_{2}, \ldots, \alpha_{13}$ are regression coefficients, (Country), (Sector), (Arco Ranking Index $2004), \ldots$, (Trade) are explanatory variables, a set of regression variables at the project and country 
level that are likely to influence the probability that project to involve technology transfer, and $\varepsilon-a$ are random variables independently and identically distributed, following a Gumbel extreme distribution.

Econometric analysis enables the evaluation of the correlations between technology transfer and explanatory variables and the determination of the specific effect of each variable on the probability that a project involves technology transfer, when all other variables are held constant. The model is very close to the models presented in literature, such as Dechezleprêtre et al. [60,67], and Zhang and Yan [68].

The regression results are combined with a rule based system, in order to define the necessary strategic actions and recommendations that will promote the effective technology transfer in the host country. In particular, the variables that are influencing technology transfer the most in the examined country lead us easily through the rule based system to the right set of strategic actions to be taken for the promotion and facilitation of effective technology transfer.

\section{Pilot Appraisal}

For the pilot application of the proposed approach, a corresponding information system was developed. The architecture of the multi-criteria information decision support system for effective technology transfer (DSS-ETT), is shown in Figure 6. It has been developed using Microsoft Access, which is a very popular tool for development of Relational Databases of relatively small size and corresponding applications. The system essentially consists of a database, a set of forms (screens) to display and enter data and reports for printing that formulate the user interface, and a set of functions in the form of subroutines and functions, written in visual basic for applications (VBA) programming language, and organized in modules or stored as forms event handlers. The system developed was designed using an open architecture, so that the user can configure the criteria and alternatives and even the parameters, without the structure being affected.

An important element of the pilot application of the methodology was the availability of real data and relevant information derived in the context of European Union (EU) projects, as well as through direct contacts with local experts, bilateral meetings and conferences organized in the particular host countries. Hence, this proved to be also very important for the assessment of the outcomes emerged, as well as the reliability and verification of results.

The methodology was integrated using appropriate tools in the information system DSS-ETT, with the aim to support policy and decision makers in the developing world in an effort to promote and stimulate effective technology transfer. The information system DSS-ETT incorporates the following main sub-systems:

- Fuzzy TOPSIS group decision support system (FT-GDSS), which integrates customised properly the multicriteria method fuzzy TOPSIS for group decision making, an extension of the TOPSIS method to the fuzzy environment, for the assessment of the developing country's energy needs and priorities.

- $\quad$ ELECTRE TRI decision support system (ET-DSS), which incorporates the multicriteria method ELECTRE TRI customised methodologically for the assessment of the most suitable sustainable energy technologies to meet a developing country's energy needs and priorities.

- Technology transfer decision support system (TT-DSS), which integrates appropriately formulated econometric model combined with a rule based system for diagnosing the current situation and the level of infrastructure of the host country, as well as the indication of specific strategies so as to achieve "real" technology transfer.

For the application of the proposed methodology through the supporting information technology (IT) system developed, five representative developing countries were chosen, namely Chile, China, Israel, Kenya and Thailand. An important element of the pilot application was the local stakeholders' involvement in the whole process and the availability of real data, input and information from related European projects. 


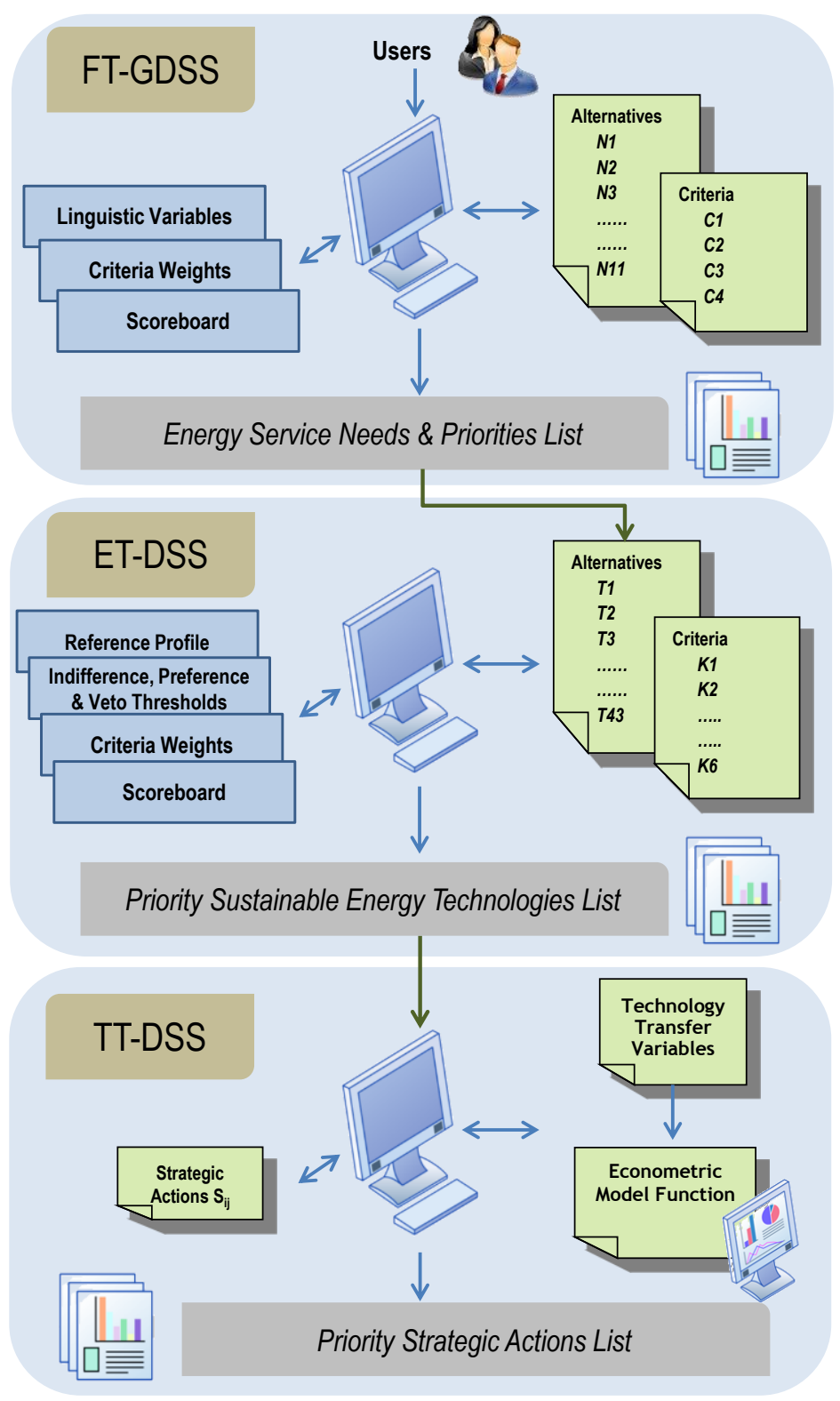

Figure 6. Information decision support system for effective technology transfer (DSS-ETT) architecture.

\subsection{Energy Services Priorities}

Based on the data collected by experts, the use of fuzzy TOPSIS for group decision-making and the review of the LOWA implementation results, the resulting as priority energy need for all the case study countries is electricity. Therefore, technologies related to electricity generation are those that will be analysed at the next step for their appropriateness to fulfil the host countries energy needs. Some comments about the results for each country are summarized below:

- Chile: Stakeholders underscored that increased access and reliable electricity for households and industry are essential. Stakeholders through the approach highlighted that increased access and reliable electricity for households and the industrial sector are essential. This is in line with the country's main considerations for energy delivery through imports and security of electricity supply for households and industry, due to energy supply instabilities the country faced in the past. 
- China: Stakeholders pointed out as a high priority for China the efficient, reliable and affordable supply of electricity and heat in industry. These needs and priorities are essential also according to national policy for the country to achieve its energy and environmental goals and ensure sustainable development.

- Israel: Israel has rapidly growing energy needs that are mainly related to electricity supply for the residential sector and the industry. The approach followed emphasized the need for increased access to reliable and affordable electricity for the residential sector, which is realistic, as this sector is responsible for the country's increasing energy consumption. Moreover, issues relating to energy security arose by local stakeholders.

- Kenya: There was a common understanding among the stakeholders that access to reliable and affordable modern energy supplies is one of the key requirements for Kenya's sustainable development. Based on the above, stakeholders' preferences led to a wide range of energy service needs and priorities and perhaps this reflects the necessity of transferring sustainable energy technologies to the country.

- Thailand: In Thailand stakeholders focused mainly on the industrial sector rather than on household sectors when assessing needs and priorities. This was explained by experts, among others from the fact that the Thai industry is characterized by increased efforts to improve energy efficiency, considering the circumstances, such as the rising energy prices and the tougher competition.

\subsection{Sustainable Energy Technologies Priorities}

For the five host countries, a number of low-carbon technologies to meet the need of electricity generation turned out for each country concerned. There are some technologies that appear to be competitive and are highly ranked in most countries. The main points from the approach's results are the following:

- Biomass is a high priority for all the countries except China, due to its sustainable characteristics and related potential to be applied. This technology seems could contribute to the sustainable development goal and there is untapped potential for implementation in all countries examined.

- Wind energy is a high priority to all countries, especially for isolated regions, since wind technology can be considered as fully commercialized and mature.

- For all case study countries oil is not considered as a high priority alternative for electricity generation. Countries tend to become independent from oil, as far as electricity generation is concerned, due to the high costs and uncertainties related with oil supply.

- Coal-to-gas is a high priority only for the case of Israel, which has great offshore natural gas reserves, has established a strategic communication to allow the import of Egyptian natural gas and tends to rely more on intern sources. On the contrary, this technology does not seem appealing for the rest of the countries due to the high import costs of natural gas.

- Electricity production of methane from coal mining is an alternative technology with great economic, environmental and social benefits, but can only be applied in countries with significant coal reserves. Therefore, only in China and Israel is this technology applicable. For the other countries examined this technology is not recommended.

\subsection{Technology Transfer Strategic Actions}

The factors identified, according to the econometric model, to positively influence technology transfer in particular host countries examined, are the macroeconomic characteristics of the country, the country's previous experience in similar projects, the size of projects, its technological capacity and the existence or not of credit buyers. It should be mentioned that the degree of influence of these factors/variables is different from country to country. 
Strategic actions to promote the effective technology transfer are customized to each host country characteristics (Table 2), so as to ensure sustainable technology transfer solutions, mainly by strengthening the existing capabilities and by creating a competitive environment.

Table 2. Priority strategic actions for the promotion of technology transfer energy services priorities.

\begin{tabular}{cccccc}
\hline Strategic Actions Categories & Chile & China & Israel & Kenya & Thailand \\
\hline Technology Information & $S_{\mathrm{a} 1}, S_{\mathrm{a} 4}$ & $S_{\mathrm{a} 2}, S_{\mathrm{a} 3}$ & $S_{\mathrm{a} 2}, S_{\mathrm{a} 3}$ & $S_{\mathrm{a} 1}, S_{\mathrm{a} 4}, S_{\mathrm{a} 5}$ & $S_{\mathrm{a} 1}, S_{\mathrm{a} 2}$ \\
Enabling Environment & $S_{\mathrm{b} 2}, S_{\mathrm{b} 3}, S_{\mathrm{b} 4}$ & $S_{\mathrm{b} 1}, S_{\mathrm{b} 3}, S_{\mathrm{b} 4}$ & $S_{\mathrm{b} 2}, S_{\mathrm{b} 3}, S_{\mathrm{b} 4}$ & $S_{\mathrm{b} 2}$ & $S_{\mathrm{b} 2}, S_{\mathrm{b} 3}, S_{\mathrm{b} 5}$ \\
Capacity Building & $S_{\mathrm{c} 1}, S_{\mathrm{c} 3}, S_{\mathrm{c} 4}, S_{\mathrm{c} 5}$ & $S_{\mathrm{c} 2}$ & $S_{\mathrm{c} 2}, S_{\mathrm{c} 3}$ & $S_{\mathrm{c} 1}, S_{\mathrm{c} 2}, S_{\mathrm{c} 3}, S_{\mathrm{c} 4}, S_{\mathrm{c} 5}$ & $S_{\mathrm{c} 1}, S_{\mathrm{c} 2}, S_{\mathrm{c} 3}$ \\
\hline
\end{tabular}

The results of the econometric model and the regression analysis, i.e. the resulting as critical parameters to enhance technology transfer in a developing country, associated with the resultant as appropriate technologies, are connected with a rule based system (if/then), in order to create a list of specific strategic actions to support and achieve "real" technology transfer. Overall, the knowledge base consists of approximately 210 rules, structured with an "if ... then ..." rule, so as to create the list of strategic actions for each host country. In particular, for Chile the strategic actions promoting technology transfer are presented in Table 3.

Table 3. Priority strategic actions for the promotion of technology transfer in Chile.

\begin{tabular}{|c|c|c|}
\hline $\begin{array}{l}\text { Strategic Actions } \\
\text { Categories }\end{array}$ & $\mathbf{A} / \mathbf{A}$ & Priority Strategic Actions in Chile \\
\hline \multirow{2}{*}{$\begin{array}{l}\text { Technology } \\
\text { Information }\end{array}$} & 1 & $\begin{array}{l}S_{\mathrm{a} 1} \text { : implementation of training programmes and workshops for building } \\
\text { capacity in technology information }\end{array}$ \\
\hline & 2 & $S_{\mathrm{a} 4}$ : elaboration of reports on the $R \& D$ needs \\
\hline \multirow{3}{*}{$\begin{array}{c}\text { Enabling } \\
\text { Environment }\end{array}$} & 3 & $S_{\mathrm{b} 2}$ : strengthening the regulatory frameworks/enhancement of legal systems \\
\hline & 4 & $S_{\mathrm{b} 3}$ : integration of technology transfer into national policies \\
\hline & 5 & $\begin{array}{l}S_{\mathrm{b} 4} \text { : bilateral and multilateral cooperation programmes for the promotion of } \\
\text { technology transfer }\end{array}$ \\
\hline \multirow{4}{*}{ Capacity Building } & 6 & $S_{\mathrm{c} 1}: \mathrm{R} \& D$ funding programs \\
\hline & 7 & $\begin{array}{l}S_{\mathrm{c} 3} \text { : activities to increase, enhance or improve awareness and knowledge of } \\
\text { sustainable energy technologies and their transfer in a host country }\end{array}$ \\
\hline & 8 & $S_{\mathrm{C} 4}:$ Establishment of national or regional R\&D centres \\
\hline & 9 & $\begin{array}{l}S_{\mathrm{C} 5} \text { : provision or support training activities for the development and transfer of } \\
\text { technologies in a host country }\end{array}$ \\
\hline
\end{tabular}

Table 4 presents the strategic actions list promoting effective technology transfer in China.

Table 4. Priority strategic actions for the promotion of technology transfer in China.

\begin{tabular}{ccl}
$\begin{array}{c}\text { Strategic Actions } \\
\text { Categories }\end{array}$ & A/A & Priority Strategic Actions in China \\
\hline $\begin{array}{c}\text { Technology } \\
\text { Information }\end{array}$ & 1 & $\begin{array}{l}S_{\mathrm{a} 2}: \text { elaboration of national communications with information on technology } \\
S_{\mathrm{a} 3}: \text { elaboration of technical studies that explore barriers, good practices } \\
\text { and recommendations }\end{array}$ \\
\hline Enabling & 3 & $\begin{array}{l}S_{\mathrm{b} 1}: \text { creation of an environment conducive to investment } \\
S_{\mathrm{b} 3}: \text { integration of technology transfer into national policies } \\
S_{\mathrm{b} 4}: \text { bilateral and multilateral cooperation programmes for the promotion of } \\
\text { technology transfer }\end{array}$ \\
\hline Caprironment & 5 & $\begin{array}{l}S_{\mathrm{c} 2}: \text { elaboration of reports on capacity-building needs and experiences of the } \\
\text { host country relating to the development, deployment, diffusion and transfer } \\
\text { of technologies }\end{array}$ \\
\hline
\end{tabular}

Table 5 presents the results emerging from the rule based system in case of Israel. 
Table 5. Priority strategic actions for the promotion of technology transfer in Israel.

\begin{tabular}{ccl}
$\begin{array}{c}\text { Strategic Actions } \\
\text { Categories }\end{array}$ & A/A & Priority Strategic Actions in Israel \\
\hline $\begin{array}{c}\text { Technology } \\
\text { Information }\end{array}$ & 1 & $\begin{array}{l}S_{\mathrm{a} 2}: \text { elaboration of national communications with information on technology } \\
S_{\mathrm{a} 3}: \text { elaboration of technical studies that explore barriers, good practices } \\
\text { and recommendations }\end{array}$ \\
\hline Enabling & 3 & $\begin{array}{l}S_{\mathrm{b} 2}: \text { strengthening the regulatory frameworks/enhancement of legal systems } \\
S_{\mathrm{b} 3}: \text { integration of technology transfer into national policies } \\
S_{\mathrm{b} 4}: \text { bilateral and multilateral cooperation programmes for the promotion of } \\
\text { technology transfer }\end{array}$ \\
\hline Environment & 5 & $\begin{array}{l}S_{\mathrm{c} 2}: \text { elaboration of reports on capacity-building needs and experiences of the } \\
\text { host country relating to the development, deployment, diffusion and transfer } \\
\text { of technologies } \\
S_{\mathrm{c} 3}: \text { Activities to increase, enhance or improve awareness and knowledge of } \\
\text { sustainable energy technologies and their transfer in a host country }\end{array}$ \\
\hline
\end{tabular}

The results emerging from the rule based system implemented in Kenya are presented in Table 6 .

Table 6. Priority strategic actions for the promotion of technology transfer in Kenya.

\begin{tabular}{|c|c|c|}
\hline $\begin{array}{l}\text { Strategic Actions } \\
\text { Categories }\end{array}$ & $\mathbf{A} / \mathbf{A}$ & Priority Strategic Actions in Kenya \\
\hline \multirow{3}{*}{$\begin{array}{l}\text { Technology } \\
\text { Information }\end{array}$} & 1 & $\begin{array}{l}S_{\mathrm{a} 1} \text { : implementation of training programmes and workshops for building } \\
\text { capacity in technology information }\end{array}$ \\
\hline & 2 & $S_{\mathrm{a} 4}:$ elaboration of reports on the $R \& D$ needs \\
\hline & 3 & $S_{\mathrm{a} 5}:$ establishment of technology information centres and networks \\
\hline $\begin{array}{c}\text { Enabling } \\
\text { Environment }\end{array}$ & 4 & $S_{\mathrm{b} 2}:$ strengthening the regulatory frameworks/enhancement of legal systems \\
\hline \multirow{6}{*}{ Capacity Building } & 5 & $S_{\mathrm{c} 1}: \mathrm{R} \& \mathrm{D}$ funding programs \\
\hline & & $S_{\mathrm{c} 2}$ : elaboration of reports on capacity-building needs and experiences of the \\
\hline & 6 & $\begin{array}{l}\text { host country relating to the development, deployment, diffusion and transfer } \\
\text { of technologies }\end{array}$ \\
\hline & 7 & $\begin{array}{l}S_{\mathrm{c} 3} \text { : activities to increase, enhance or improve awareness and knowledge of } \\
\text { sustainable energy technologies and their transfer in a host country }\end{array}$ \\
\hline & 8 & $S_{\mathrm{c} 4}:$ establishment of national or regional R\&D centres \\
\hline & 9 & $\begin{array}{l}S_{\mathrm{c} 5}: \text { provision or support training activities for the development and transfer of } \\
\text { technologies in a host country }\end{array}$ \\
\hline
\end{tabular}

Strategic actions promoting technology transfer in Thailand are presented in Table 7.

The factors that are affecting technology transfer positively in the five under examination host countries are: the macroeconomic features of the country, the given existence or lack of respective projects, the size of these projects, the technological potential in the developing country and the presence or absence of credit buyers. Regarding this conclusion, it should be mentioned the impact and influence of each of these factors varies from country to country.

This may seem as a paradox at a first reading, but it can be explained by the fact that developing countries have different key characteristics. These key characteristics mainly concern the country's human capital in terms of skills and expertise (knowledge, techniques and management skills), the technology base in terms of manufacturing capacity, supply chain capacity, end-of-life/waste disposal, and institutional capacity. In addition, it is also crucial, the educational level of the domestic scientific community and its potential to absorb and future exploit the "imported" expertise, the R\&D infrastructure available to scientists, and the priorities of the government policy related to these specific projects. Finally, it should not be overlooked that the previous experience that the country had in such projects plays an important role, as well as particularities, such as the topography or even the 
availability of natural resources, which indirectly define the variety of different infrastructure projects, interesting the host country technically and economically.

The strategic actions promoting effective technology transfer were customized in each host country specific characteristics. Therefore, the application of the methodology resulted in concrete actions that ensure sustainable technology transfer solutions mainly by strengthening the existing capacity and creating a competitive environment.

Table 7. Priority strategic actions for the promotion of technology transfer in Thailand.

\begin{tabular}{ccl}
\hline $\begin{array}{c}\text { Strategic Actions } \\
\text { Categories }\end{array}$ & A/A & Priority Strategic Actions in Thailand \\
\hline $\begin{array}{c}\text { Technology } \\
\text { Information }\end{array}$ & 1 & $\begin{array}{l}S_{\mathrm{a} 1} \text { : implementation of training programmes and workshops for building } \\
\text { capacity in technology information }\end{array}$ \\
\hline Enabling & 2 & $S_{\mathrm{a} 2}:$ elaboration of national communications with information on technology \\
\hline Environment & 4 & $\begin{array}{l}S_{\mathrm{b} 2}: \text { strengthening the regulatory frameworks/enhancement of legal systems } \\
S_{\mathrm{b} 3}: \text { integration of technology transfer into national policies } \\
S_{\mathrm{b} 5}: \text { policy arrangements for the promotion of international scientific and } \\
\text { technological cooperation }\end{array}$ \\
\hline Capacity Building & 7 & $\begin{array}{l}S_{\mathrm{c} 1}: \text { R\&D funding programs } \\
S_{\mathrm{c} 2}: \text { elaboration of reports on capacity-building needs and experiences of the } \\
\text { host country relating to the development, deployment, diffusion and transfer } \\
\text { of technologies } \\
S_{\mathrm{c} 3}: \text { activities to increase, enhance or improve awareness and knowledge of } \\
\text { sustainable energy technologies and their transfer in a host country }\end{array}$ \\
\hline
\end{tabular}

\section{Conclusions}

As the issues and goals of climate change policy and development are inseparable, and interact in a circular fashion, there is growing recognition that these issues should be regarded together. An important benefit of this new line of thinking, the embedding of emission reduction in countries' domestic sustainable development policies, is that developing countries may be better enabled to identify and accept greenhouse gas emission reduction measures, as these would also support achieving domestic development goals.

Developing countries often choose an energy technology profile that may not be the "best" in terms of delivering long term sustainability. The rapid growth, combined with up-to-date technological knowledge provides developing countries opportunities to avoid bad and unsustainable practices of the past and move faster towards clean and sustainable technologies and techniques. In this effort, developing countries need to be supported in capacity building, in the development of appropriate tools and networks, as well as in the acquisition of specific technologies.

In most cases, developing countries implement energy projects without considering the possibility of technology transfer and its benefits nor the contribution to the country's sustainable development goals. The process of an effective technology transfer is strongly participatory, as it requires stakeholder input at each stage. It is, therefore, highlighted the need of an integrated decision support system leading to a national technology development and transfer accelerating strategy for input to country climate change and development plans.

The methodological framework AID and the information DSS-ETT system, effectively support policy makers in the developing world to promote effective technology transfer. The DSS-ETT system addresses the problem of technology transfer in accordance, not only to the country's short-term energy needs and priorities, but also to the long-term energy and development priorities, as these can be changed in the light of climate change. One of its main advantages is that apart from being user friendly and adjusted in accordance to each analyst needs, the user can also easily extract data. In addition, the structure of the econometric model is very simple and the user can easily enhance it with new variables that could affect technology transfer in the future. Important features are the 
introduction of the technic of group decision making, indispensable for the nature of the specific problem, as well as the econometric model configuration to support decisions making, which is a major breakthrough, when considering that it is used for proposing concrete strategies for the effective technology transfer in the developing world.

The pilot appraisal in Chile, China, Israel, Kenya, and Thailand supported by the information system developed, enabled the assessment of the characteristics of the proposed methodology in terms of completeness, usability, extensionality, as well as analysis of results reliability. When looking at the results in each methodological step the following could be noted:

- Energy Needs and Priorities: The high priority energy need that emerged for all the five host countries examined through the pilot application of the proposed methodology, taking into account the overall medium to long-term energy and environmental strategy of each developing country is electricity production.

- High Priority Sustainable Energy Technologies: Climate change may change the host country's energy needs over time and this, as expected, affects the technological needs of the country. The results led to technologies related to the domestic energy potential of these countries. The priority sustainable energy technologies are fully commercialized and matured enough, with significant sustainability benefits, economic, environmental and social, for the host countries.

- Strategic Technology Transfer Actions: The transfer of sustainable energy technologies should be linked to the country's national strategies, while strengthening the local economic activity, capacity and infrastructure. By identifying the factors influencing technology transfer in the five host countries, the application proposed concrete strategic actions promoting the effective technology transfer, directly linked to the resulting as priority sustainable energy technologies in each host country under examination.

The paper investigated the problem of identifying concrete actions to promote technology transfer with the frame of climate change mitigation. However, the methodology and analysis proposed could also easily be customised to identifying and prioritizing activities in terms of their contribution to climate change adaptation also, leading to sustainable development in a climate challenged world. Therefore, the AID approach, as a country-based participatory process, could feed into the technology needs assessments (TNAs), the nationally appropriate mitigation actions (NAMAs), as well as the intended nationally determined contributions (INDCs). This reduces the need for developing countries to do multiple separate exercises and would support that the outputs for mitigation and adaptation strategies and action plans will deliver the sustainable development benefits for countries. Furthermore, an application of this methodology to great group of developing countries, could provide important insights from a comparative analysis between countries and regions and draw global conclusions on the methods and procedures, as well as for the progress and benefits derived from technology transfer.

Acknowledgments: Charikleia Karakosta wishes to acknowledge with gratitude the Alexander S. Onassis Public Benefit Foundation for supporting her Ph.D research.

Conflicts of Interest: The author declare no conflict of interest. The founding sponsors had no role in the design of the study; in the collection, analyses, or interpretation of data; in the writing of the manuscript, and in the decision to publish the results.

\section{References}

1. Hoekman, B.M.; Maskus, K.E.; Saggi, K. Transfer of technology to developing countries: unilateral and multilateral policy options. World Dev. 2005, 33, 1587-1602. [CrossRef]

2. Ojoo-Massawa, E. Sustainable Development Benefits Delivered by the Clean Development Mechanism; National Environment Management Authority (NEMA): Nairobi, Kenya, 2007.

3. Popp, D. International Technology Transfer for Climate Policy, Policy Brief; Syracuse University, Center for Policy Research, Maxwell School of Citizenship and Public Affairs: Syracuse, NY, USA, 2008. 
4. Doukas, H.; Patlitzianas, D.K.; Papadopoulou, A.; Psarras, J. Foresight of innovative energy technologies through a multi criteria approach. Int. J. Energy Technol. Policy 2008, 6, 381-394. [CrossRef]

5. Ockwell, G.D.; Watson, J.; MacKerron, G.; Pal, P.; Yamin, F. Key policy considerations for facilitating low carbon technology transfer to developing countries. Energy Policy 2008, 36, 4104-4115. [CrossRef]

6. Leal-Arcas, R.; Carafa, L. Road to Paris COP21: Towards soft global governance for climate change. Renew. Energy Law Policy Rev. 2014, 2, 130-135.

7. Karakosta, C.; Doukas, H.; Psarras, J. A decision support approach for the sustainable transfer of energy technologies under the Kyoto protocol. Am. J. App. Sci. 2008, 5, 1720-1729. [CrossRef]

8. Wilkins, G. Technology Transfer for Renewable Energy: Overcoming Barriers in Developing Countries; Royal Institute of International Affairs/Chatham House: London, UK, 2002.

9. Ramanathan, R. Successful transfer of environmentally sound technologies for greenhouse gas mitigation: A framework for matching the needs of developing countries. Ecol. Econ. 2002, 42, 117-129. [CrossRef]

10. Karakosta, C.; Doukas, H.; Psarras, J. Technology transfer through climate change: Setting a sustainable energy pattern. Renew. Sustain. Energy Rev. 2010, 14, 1546-1557. [CrossRef]

11. Karakosta, C.; Askounis, D. Developing countries' energy needs and priorities under a sustainable development perspective: A linguistic decision support approach. Energy Sustain. Dev. 2010, 14, 330-338. [CrossRef]

12. Karakosta, C.; Doukas, H.; Psarras, J. Directing clean development mechanism towards developing countries' sustainable development priorities. Energy Sustain. Dev. 2009, 13, 77-84. [CrossRef]

13. Implementation of the Poznan Strategic Program on Technology Transfer: A Progress Report of the GEF to the Subsidiary Body for Implementation at its Thirty-Second Session; Global Environment Facility (GEF): Washington, DC, USA, 2010.

14. Burns, A.; Timmer, H.; Riordan, E.M.; Shaw, W.; David, A.; Decreux, Y.; Sulla, O. Global Economic Prospects: Technology Diffusion in the Developing World; The World Bank: Washington, DC, USA, 2008.

15. Report of the Conference of the Parties on its Fourteenth Session, held in Poznan from 1 to 12 December 2008; Part One; United Nations Framework Convention on Climate Change (UNFCCC): Geneva, Switzerland, 2009.

16. Kowalski, K.; Stagl, S.; Madlener, R.; Omann, I. Sustainable energy futures: methodological challenges in combining scenarios and participatory multi-criteria analysis. Eur. J. Oper. Res. 2009, 197, 1063-1074. [CrossRef]

17. Karakosta, C.; Flamos, A.; Doukas, H.; Vaturi, A. Sustainable energy technology transfers through the CDM? Application of participatory approaches for decision making facilitation. Int. J. Environ. Policy Decis. Mak. 2010, 1, 1-16. [CrossRef]

18. Karakosta, C.; Doukas, H.; Psarras, J. CDM Sustainable Technology Transfer Grounded in Participatory In-Country Processes in Israel. Int. J. Sustain. Soc. 2011, 3, 225-242. [CrossRef]

19. Chen, T.C. Extensions of the TOPSIS for group decision making under fuzzy environment. Fuzzy Sets Syst. 2000, 114, 1-9. [CrossRef]

20. Karakosta, C.; Psarras, J. Fuzzy TOPSIS approach for understanding a country's development priorities within the scope of climate technology transfer. Adv. Energy Res. 2012, 9, 123-149.

21. Herrera, F.; Herrera-Viedma, E. Linguistic decision analysis: steps for solving decision problems under linguistic information. Fuzzy Sets Syst. 2000, 115, 67-82. [CrossRef]

22. Mousseau, V.; Slowinski, R. Inferring an ELECTRE TRI model from assignment examples. J. Glob. Optim. 1998, 12, 157-174. [CrossRef]

23. Mousseau, V.; Slowinski, R.; Zielniewicz, P. ELECTRE TRI 2.0 a Methodological Guide and User's Manual. Doc. LAMSADE 1999, 111, 263-275.

24. Albu, M.; Griffith, A. Mapping the Market: A Framework for Rural Enterprise Development Policy and Practice; Practical Action Publishing: Warwickshire, UK, 2005.

25. Subbarao, S.; Lloyd, B. Can the clean development mechanism (CDM) deliver? Energy Policy 2011, 39, 1600-1611. [CrossRef]

26. Bazeley, P.; Richards, L. The NVivo Qualitative Project Book; Sage Publications Inc.: London, UK, 2000.

27. NVivo Qualitative Data Analysis Software; Version 7; QSR International Pty Ltd.: Doncaster, Australia, 2006.

28. Goldman, L.I. Crystal Ball Professional Introductory Tutorial. In Proceedings of the Simulation Conference of the Winter, San Diego, CA, USA, 8-11 December 2002; Volume 2, pp. 1539-1545. 
29. Doukas, H.; Botsikas, A.; Psarras, J. Multi-criteria decision aid for the formulation of sustainable technological energy priorities using linguistic variables. Eur. J. Oper. Res. 2007, 182, 844-855. [CrossRef]

30. Doukas, H.; Karakosta, C.; Psarras, J. Computing with words to assess the sustainability of renewable energy options. Expert Syst. Appl. 2010, 37, 5491-5497. [CrossRef]

31. Doukas, H. Modelling of linguistic variables in multicriteria energy policy support. Eur. J. Oper. Res. 2013, 227, 227-238. [CrossRef]

32. Doukas, H.; Tsiousi, A.; Marinakis, V.; Psarras, J. Linguistic multi-criteria decision making for energy and environmental corporate policy. Inf. Sci. 2014, 258, 328-338. [CrossRef]

33. ENTTRANS Report Summary: The Potential of Transferring and Implementing Sustainable Energy Technologies through the Clean Development Mechanism of the Kyoto Protocol; The European Commission: Groningen, The Netherlands, 2008.

34. Karakosta, C.; Marinakis, V.; Letsou, P.; Psarras, J. Does the CDM Offer Sustainable Development Benefits or not? Int. J. Sustain. Dev. World Ecol. 2013, 20, 1-8. [CrossRef]

35. Karakosta, C.; Doukas, H.; Psarras, J. Sustainable energy technologies in Israel under the CDM: Needs and prospects. Renew. Energy 2009, 34, 1399-1406. [CrossRef]

36. Brito, A.J.; De Almeida, A.T.; Mota, C.M. A multicriteria model for risk sorting of natural gas pipelines based on ELECTRE TRI integrating utility theory. Eur. J. Oper. Res. 2010, 200, 812-821. [CrossRef]

37. Wang, J.J.; Jing, Y.Y.; Zhao, J.H. Multi Criteria Evaluation Model of Renewable Energy Power Plants Based on ELECTRE Method. In Proceedings of the ASME 2009 3rd International Conference on Energy Sustainability, San Francisco, CA, USA, 19-23 July 2009; pp. 467-473.

38. Yu, W. ELECTRE TRI: Aspects Méthodologiques et Manuel d'Utilisation; Document-Université de Paris-Dauphine, LAMSADE: Dauphine, Paris, 1992. (In French)

39. Doukas, H.; Karakosta, C.; Psarras, J. RES technology transfer within the new climate regime: A "Helicopter" view under the CDM. Renew. Sustain. Energy Rev. 2009, 13, 1138-1143. [CrossRef]

40. Joint Implementation Quarterly. ENTTRANS: Assessment of Technology Implementation Chains in CDM Host Countries. Magazine on the Kyoto Mechanisms: Paterswolde, The Netherlands, 13 July 2007; Magazine on the Kyoto Mechanisms: Paterswolde, The Netherlands, 13 July 2007; 6-7.

41. Matysek, A.; Ford, M.; Jakeman, G.; Gurney, A.; Fisher, S.B. Technology: Its Role in Economic Development and Climate Change; Canberra, Australian Bureau of Agricultural and Research Economics (ABARE): Canberra, Australia, 2006.

42. Renewables "Global Status Report"; Renewable Energy Policy Network for the 21st Century: Paris, France, 2010.

43. The World Alliance for Decentralized Energy; The World Alliance for Decentralized Energy (WADE): Edinburgh, UK, 2003.

44. Clean Coal—Building a Future through Technology; World Coal Institute (WCI): London, UK, 2004.

45. Bazmi, A.A.; Zahedi, G. Sustainable energy systems: Role of optimization modeling techniques in power generation and supply-A review. Renew. Sustain. Energy Rev. 2011, 15, 3480-3500. [CrossRef]

46. Chai, Q.; Zhang, X. Technologies and policies for the transition to a sustainable energy system in China. Energy 2010, 35, 3995-4002. [CrossRef]

47. European Union (EU) Directive E.C.32/EC of the European Parliament and of the Council of 5 April 2006 on Energy End-Use Efficiency and Energy Services and Repealing Council Directive 93/76/EEC, (Text with EEA relevance). Off. J. Eur. Union 2006, 114, 64-84.

48. European Union (EU) Directive 2009/28/EC of the European Parliament and of the Council of 23 April 2009 on the Promotion of the Use of Energy from Renewable Sources and Amending and Subsequently Repealing Directives 2001/77/EC and 2003/30/EC, (Text with EEA relevance). Off. J. Eur. Union 2009, 140, $16-62$.

49. European Union (EU) Directive 2010/31/EU of the European Parliament and of the Council of 19 May 2010 on the Energy Performance of Buildings (recast). Off. J. Eur. Union 2010, 153, 13-35.

50. Jansen, L. The challenge of sustainable development. J. Clean. Prod. 2003, 11, 231-245. [CrossRef]

51. Lior, N. Sustainable energy development: The present (2009) situation and possible paths to the future. Energy 2010, 35, 3976-3994. [CrossRef]

52. CDM Methodology Booklet_Information including EB 56; United Nations Framework Convention on Climate Change (UNFCCC): Geneva, Switzerland, 2010; p. 212.

53. Pappas, C.; Karakosta, C.; Marinakis, V.; Psarras, J. A comparison of electricity production technologies in terms of sustainable development. Energy Convers. Manag. 2012, 64, 626-632. [CrossRef] 
54. Karakosta, C.; Marinakis, V.; Psarras, J. Supporting decision makers in assessing environmental policy instruments. In Renewable Energy: Economics, Emerging Technologies and Global Practices; Poullikkas, A., Ed.; Nova Science Publishers Inc.: Hauppauge, NY, USA, 2013; pp. 15-24.

55. Karakosta, C.; Psarras, J. Redefining the clean development mechanism to encourage the transfer of sustainable energy technologies. Int. J. Energy Environ. Econ. 2009, 17, 143-158.

56. Fenhann, J. CDM Pipeline Overview. Available online: http://uneprisoe.org/ (accessed on 20 June 2013).

57. Clean Development Mechanism Project Design Document Form (CDM PDD); Version 03.1; United Nations Framework Convention on Climate Change (UNFCCC): New York, NY, USA, 2006.

58. Project Cycle Search; United Nations Framework Convention on Climate Change (UNFCCC): New York, NY, USA, 2011. Available online: http://cdm.unfccc.int/Projects/projsearch.html/ (accessed on 5 December 2012).

59. Balachandra, P.; Nathan, H.S.K.; Reddy, B.S. Commercialization of sustainable energy technologies. Renew. Energy 2010, 35, 1842-1851. [CrossRef]

60. Dechezleprêtre, A.; Glachant, M.; Ménière, Y. Technology transfer by CDM projects: A comparison of Brazil, China, India and Mexico. Energy Policy 2009, 37, 703-711. [CrossRef]

61. Delina, L.L. Clean energy financing at Asian Development Bank. Energy Sustain. Dev. 2011, 15, $195-199$. [CrossRef]

62. Okazaki, T.; Yamaguchi, M. Accelerating the transfer and diffusion of energy saving technologies steel sector experience-Lessons learned. Energy Policy 2011, 39, 1296-1304. [CrossRef]

63. Thorne, S. Towards a framework of clean energy technology receptivity. Energy Policy 2008, 36, $2831-2838$. [CrossRef]

64. Van der Gaast, W.; Begg, K.; Flamos, A. Promoting sustainable energy technology transfers to developing countries through the CDM. Appl. Energy 2009, 86, 230-236. [CrossRef]

65. Wang, B. Can CDM bring technology transfer to China?-An empirical study of technology transfer in China's CDM projects. Energy Policy 2010, 38, 2572-2585. [CrossRef]

66. Zhao, Z.Y.; Zuo, J.; Feng, T.T.; Zillante, G. International cooperation on renewable energy development in China-A critical analysis. Renew. Energy 2011, 36, 1105-1110. [CrossRef]

67. Dechezleprêtre, A.; Glachant, M.; Ménière, Y. The clean development mechanism and the international diffusion of technologies: An empirical study. Energy Policy 2008, 36, 1273-1283. [CrossRef]

68. Zhang, C.; Yan, J. CDM's influence on technology transfers: A study of the implemented clean development mechanism projects in China. Appl. Energy 2015, 158, 355-365. [CrossRef] 